\title{
Buddhist and Muslim Interaction in the Post-War of Sri Lanka
}

\author{
AHAMED SARJOON RAZICK, IQBAL SAUJAN \& SEYYATH MOHAMMED HAKEEMA BEEVI ${ }^{1}$
}

\begin{abstract}
Sri Lanka is a small pluralistic state. This is a multi-racial social environment, members of all communities lived in peace and harmony with social integration with one another. Each community practised and its own religious cultural values. This situation has changed aftermath of the government's victory in the war (1983-2009) against the Liberation Tigers Tamil Elam (LTTE). Now there is a series of tense between the Buddhist and Muslim communities in Sri Lanka. The Buddhist Nationalist Groups (BNGs) have been questioned the social and religious features of the Muslims, and their religious obligations were heavily and unduly questioned via provocations from these respective groups. On this background, the study attempts to explore the religious interaction between Muslims and Buddhists in Sri Lanka. The questionnaire survey used as a key tool, and the semi-structured interview conducted among the Buddhists and Muslims in Sri Lanka. The findings of the study show that the relationship between the two communities is generally seen to be in a healthy state. However, the few notable features have exacerbated the tension between the two communities.
\end{abstract}

Keywords: Buddhists, Muslims, Interaction, post-war context of Sri Lanka, religions understanding

In Sri Lanka, a multi-religious country, members of various communities once lived in peace and harmony with each other. Each community practiced and preserved its own religious and cultural identity while sharing and respecting each other's religious and cultural values. The Sinhalese are the main ethnic group in the country constituting three quarters of the total population. Among them, the Sinhalese-Buddhists make up 70.19\% (Department of Census and Statistics 2012) and speak Sinhala, an Indo-Aryan language. The Tamils make up the second major ethnic group, constituting $15.37 \%$ of the population. This group consists of Sri Lankan Tamils and Indian Tamils, of which $12.61 \%$ are Hindus (Department of Census and Statistics, 2012). The Muslims in Sri Lanka constitute only $9.4 \%$ of the country's population (Department of Census and Statistics 2012) and speak Tamil, a Dravidian language and live in various parts of the country.

The interaction between Buddhists and Muslims emerged from the pre-Islamic Arab relationship with Sri Lanka. The Arabs who built vibrant trade relationship with Sri Lanka married Sinhala-Buddhist women and kept their ancestor. Here and made Sri Lanka their second habitation. With the emergence of Islam in the $7^{\text {th }}$ Century the Arabs became Muslims; thus the Arab-Muslim association with Sri Lanka became stronger and tied up with the ancestry of Islam as a global authority. Consequently, the relationship that initiated as commercial links was extended to other sectors such as local and international trade, defence, and diplomatic relationship, especially in the pre-colonial (before 1505) and colonial times (1505-1948). This connection with the Buddhist community has grown over a very long period of time and developed with trust and good understanding (Razick 2017).

However, in 1915, this tied interaction was exploited by the British colonialist and their affiliates of the time putting a block in the Buddhist-Muslim link as a strategy to divide and policy (Yehiya 2013). To a lesser extent, the British colonial administration (1796-1948) and their affiliates

\footnotetext{
${ }^{1}$ Ahamed Sarjoon Razick, Ph. D. ( ${ }^{*}$ Corresponding author), Dept. of Islamic Studies, South Eastern University of Sri Lanka, University Park, Ouluvil, SRI LANKA. Email: sarjoonra@seu.ac.lk; Iqbal Saujan, B.A (Hons.), Dept of Islamic Studies, South Eastern University of Sri Lanka, University Park, Ouluvil, SRI LANKA. Email: saujaniqbal95@gmail.com; Eyyathu Mohamed Hakeema Beevi, B.A (Hons.), Dept. of Islamic Studies, South Eastern University of Sri Lanka University Park, Ouluvil, SRI LANKA. Email: hakee97693@gmail.com
} 
somewhat succeeded in dividing these two communities as a strategy to prevent the communities challenging the Western imperial grand plan of exploiting and controlling resources in the colony. In spite of this external set-up causing division, the social interaction persisted and the paradigm of relationship between Buddhists and Muslims has brought about bond that carries an unwritten deal on each other to protect and guarantee mutual security.

So, except 1915 riots, there were no more records in the history of any rupture between these two communities till the end of war (1983-2009) which held between the Government and the LTTE in the country. However, in recent years, especially after 2011 onwards there is a nature of tension between the Buddhist and Muslim communities due to the range of hate campaigns carried out by a number of Buddhist Nationalist Groups (BNGs) against Muslims and their socio-culture. Consequently, a suspicious situation began to develop as to whether this could have divided the societies in Sri Lanka.

\section{Statement of the Problem}

Sri Lanka, in recent times, especially in the aftermath of the government's victory in the war (19832009) against the Liberation Tigers Tamil Elam (LTTE) has witnessed a series of tense situations between the Buddhist and Muslim communities. The Buddhist Nationalist Groups (BNGs) consisting of Buddhist monkhood organizations such as Bodu Bala Sena (BBS), Sinhala Rawaya (SR), Rawana Balaya (RB) and Sinha Le instigated these issues by questioning the social and religious features of the Muslim community. The formation of these groups began after 1956 when Parties such as the SLFP and UNP gave priority to Buddhism and following S.W.RT. Bandaranaik's campaign to make Sinhala the official language (Ahamed Sarjoon, Mohamed Anifa \& Abdul Kalik 2020). Therefore, Muslim behaviours related to religious obligations were heavily and unduly questioned via provocations from these respective groups. During their rallies and conferences, the prominent hard-liner groups have not shied away from using coarse, hateful speeches to undermine and question Muslims and their religious practices, and spread misunderstandings and misperception about them among the majority Buddhist community in Sri Lanka (CPA 2013), especially, these groups have propagated and advised Buddhists to reduce or avoid cultural and economic interactions as well as ban any relationship with the Muslim community.

These incidents have created a tense situation that is rife with suspicion. The Muslims have begun to feel marginalized, especially those who live in Buddhist-populated areas throughout the country. Moreover, these incidents have contributed to clashes in opinions and misunderstandings, thus further damaging the healthy interaction that was stronger between the Buddhists and Muslims in Sri Lanka. Although Muslims are seen as having remained largely loyal to the state during the 30-year ethnic conflict and civil war (Rifai 2013), they are currently expressing fear of religious marginalization, which has increased the uncertainty of their co-existence and long-term cordial relationship with other major ethno-religious groups, especially Buddhists. Given the above background, this study attempts to accomplish the following 3 major objectives through a questionnaire survey and a semi-structured interview conducted among the Buddhists and Muslims in Sri Lanka.

\section{Objectives and Significance of the Study}

The objective of this study is to explore the religious interaction between Muslims and Buddhists in Sri Lanka. In order to measure the quality of interaction, some indicators such as religious understandings, mixed interaction, sharing work place, sharing leisure time together, factors that promote and stifle interaction have been prepared to be applied on the respondents who will be chosen from Buddhists and Muslims.

The significance of the study lies mainly in showing the level of social interaction between two ethno-religious groups (Buddhists and Muslims) in Sri Lanka through measuring religious understandings, mixed interactions, sharing workplace and sharing leisure time together. Also, the study expands the existing list of literatures on the Buddhist-Muslim interaction in Sri Lanka. Further, this study recommends measures to strengthen ethnic reconciliation and interaction between religious groups to build peace and harmony among the communities in Sri Lanka. 


\section{Conceptual Note on Social Interaction}

As this study attempts to find the nature of social interaction among Buddhists and Muslims, it is necessary to discuss the general and religious perspectives of social interaction. Since this study is directly related to Buddhists and Muslims, it is necessary to discuss particularly about the views of Buddhism and Islam on social interaction. So, the following subsections discuss the guidelines of social interaction in general and the respective religious perspectives.

\section{Social Interaction: A General Perspective}

The word "social" refers to humankind, living together in organized groups. It also involves the mutual relations and welfare of individuals. David and Jary $(1991,245)$ define "social" as pertaining to human society and to human interaction in groups and organizations. The word "interaction" carries different connotations in various disciplines. In Sociology, it is defined as "a mutual or reciprocal action" between two or more individuals or between groups (Borgatta \& Borgatta, 1992). In the same source, interaction is generally defined as "a dynamic interplay and relationship of joint determination between two or more variables" (Goldberger \& Breznitz 1998, 37). For them, interaction also carries the meaning of "basic social process represented in communication and a mutual relationship between two or more individuals or groups" (Brislin \& Yoshida 1993, 95). Adamolekun (2012) defines "interaction" as an activity of talking to other people and understanding them. Goffman (2010) defines it is a reciprocal action and is the process by which we act and react to those around us. In the book of E. Shaw (1981), "interaction" is defined as the process by which individuals emit behaviour in each other's presence; they create products of each other, or communicate with each other (Cited by Alwi \& Rashid 2011).In a nutshell, social interaction includes those acts people perform toward each other and the responses they give in return. Social interaction is the process of changing the sequence of social actions between individuals or groups who modify their actions and reactions according to the actions by their interacting partners (Alwi \& Rashid 2011). Also, it is a dynamic interplay and relationship of joint determination between two or more variables (Cushner \& Brislin 1997).

\section{Social Interaction: Islamic Perspective}

The basic principles of social interaction are prescribed in the Holy Quran and Hadith of Prophet Muhammad. There are several verses in the Holy Quran which deal with adherence of other religions. In fact, there is a verse that cited numerous guidelines that urge humanity to engage in meaningful social interaction. The verse of Al-Quran (60:08) says that:

\footnotetext{
"Allah does not forbid you (Muslims) to deal justly and kindly with those who have not fought against you in accounts of your religion and who do not drive you out from your homes. Verily, Allah loves those who deal with equity."
}

The above Quranic verse clearly states the normal and original state for a good relationship of Muslims with Non-Muslims. Here Allah did not forbid Muslims from establishing a good interaction with NonMuslims. The verse clearly explains that the relationships with Non-Muslims should be based on the best morals and justice with those who declared peace upon Muslims and did not fight with them. Further, this verse uses the word, 'birr' which is typically used to describe the utmost interaction one could have with parents. Also uses birr to describe the type of relationship the Muslims should have with Non-Muslims. Birr includes all the good things that a relationship should have and excludes all the bad aspects of a relationship. For that reason, Muslim scholars said that birr is the foundation of the social interaction between Muslims and Non-Muslims (Baianonie 2002).

It could also be seen through a well-known Hadith which addresses the issue of association among people. This verse was revealed after the story of Asma' and her mother. Imams Bukhari, Muslim and Ahmad reported that Asma' the daughter of Abu Bakr said: 
"My mother came to me while she was still a polytheist, so I asked Allah's Messenger (Peace be upon him), "My mother, who is ill-disposed to Islam, has come to visit me. She wants something from me. Shall I maintain relations with her?" He (PBUH) replied, "Yes, maintain relations with your mother."

\section{Social Interaction: Buddhist Perspective}

Buddhism also promotes its adherents towards peaceful and harmonious way of living. In order for Buddhists to attain peace in this life, tolerance should be practiced. Tachibana $(1975,237-239)$ has commented over the ethical conduct of Buddha as: " The Buddha himself was a person of a wonderful tolerant nature, he showed an unparalleled toleration, even in the case in which his disciples committed offences, the Buddha never used any harsh language, but simply rebuked them gently for their committal, no angry words came out of his mouth in these time".

In the case of social interaction, Buddhism taught and urged its adherents to engage in social interaction with all folks of humanity. Some Buddhist perspectives on social interaction are to attain a meaningful life that stated in the guidebook called Di Zi Gui (2005). The teachings employed in that book are: "Human beings, regardless of nationality, race, or religion - everyone - should be loved equally. We are all sheltered by the same sky and we all live on the same planet earth" (Di Zi Gui 2005: 65); "A person of high ideals and morals is highly respected. What people value is not based on outside appearance" (Di Zi Gui 2005: 65), and; “A person's outstanding abilities will naturally endow him with a good reputation. Admiration from others does not come from boasting or praising oneself" (Di Zi Gui 2005: 65-66). All statements show that the main aim of Buddhism is to guide every human towards a noble life without harming other persons, cultivate humane qualities in order to maintain human dignity, spread out all-embracing kindness without any discrimination, and purify the mind to gain peace and happiness.

\section{Framework or Developing Conceptual Theory}

The objective of this study achieved through the following framework what consisted of questionnaire's questions. According to the conceptual theory social interaction would be focused in four stages particularly. As for this questionnaire was divided into four section each section has three to six specific questions that lead to the inquiry of social interactions.

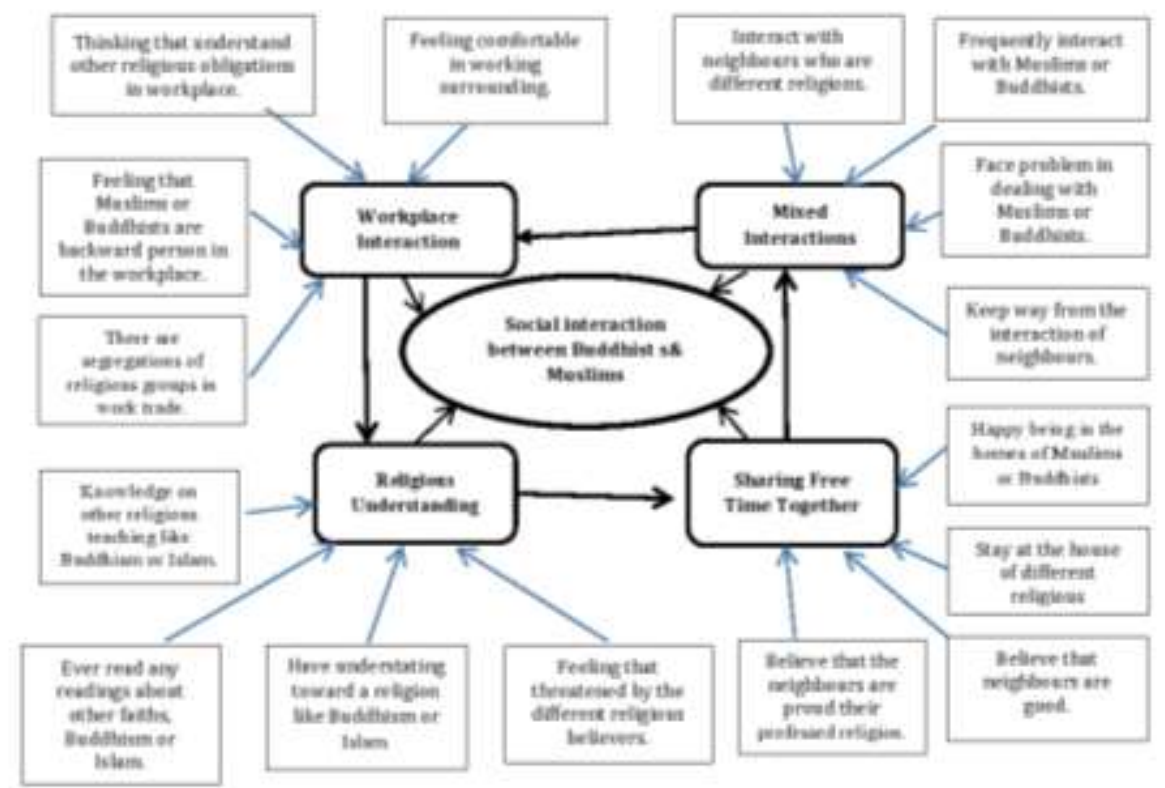

A set of questionnaires have been used to measure the level of social interaction between Buddhists and Muslims in Sri Lanka. The survey includes the Buddhist and Muslim population who reside in 14 major https://doi.org/10.24035/ijit.20.2021.206 
districts of Sri Lanka. Those are Colombo, Gampaha, Kandy, Matale, Kalutara, Matara, Anuradapura, Polonnaruwa, Ratnapura, Kegalle, Puttalam, Kurunegala, Badulla, and Moneragala districts have been selected because both Buddhist majority and Muslim minority live together side by side. The survey participants have been general public as probability, randomly selected from the above districts. The participants have been selected based on the percentage of the population in each district from the total population of Sri Lanka. For the purpose of measuring the interaction between Buddhists and Muslims, 1219 self-administered and closed-ended questionnaires have been distributed among participants in each district. The above sample has been selected for the population of 13 million people according to the table of Krejcie \& Morgan (1970) (The table for determining sample size for a given population). As the Buddhist and Muslim participants are the focus of this study, the questionnaires have been prepared in English and been translated it into both Sinhala and Tamil languages for obtaining a better response from the participants.

Questionnaire Distribution in 14 Districts

\begin{tabular}{|l|l|c|c|c|c|}
\hline S.No. & Districts & Buddhists & $\begin{array}{c}\text { Number of } \\
\text { Questionnaires }\end{array}$ & Muslims & $\begin{array}{c}\text { Number of } \\
\text { Questionnaires }\end{array}$ \\
\hline 01 & Colombo & $1,632,225$ & 120 & 274,087 & 81 \\
\hline 02 & Gampaha & $1,642,767$ & 120 & 112,746 & 33 \\
\hline 03 & Kalutara & $1,018,909$ & 70 & 114,556 & 34 \\
\hline 04 & Kandy & $1,009,220$ & 70 & 197,076 & 8 \\
\hline 05 & Matale & 385,151 & 25 & 45,682 & 59 \\
\hline 06 & Matara & 766,323 & 50 & 25,614 & 13 \\
\hline 07 & Kurunegala & $1,431,632$ & 100 & 118,305 & 35 \\
\hline 08 & Puttalam & 329,705 & 20 & 150,404 & 44 \\
\hline 09 & Anuradapura & 775,366 & 50 & 71,493 & 21 \\
\hline 10 & Polonnaruwa & 364,229 & 20 & 30,465 & 09 \\
\hline 11 & Badulla & 591,799 & 40 & 47,192 & 08 \\
\hline 12 & Moneragala & 426,762 & 30 & 9,809 & 18 \\
\hline 13 & Ratnapura & 943,464 & 70 & 24,446 & 14 \\
\hline 14 & Kegalle & 709,917 & 50 & 61,164 & 07 \\
\hline \multicolumn{7}{|l|}{ Total } & $\mathbf{1 2 0 2 7 4 6 9}$ & $\mathbf{8 3 5}$ & $\mathbf{1 2 8 3 0 3 9}$ & $\mathbf{3 8 4}$ \\
\hline
\end{tabular}

Table 1: Questionnaire Distribution in 14 Districts

In this study, researcher used a form of interview which is semi structure dafter the distribution of the questionnaires. 42 interviews, 3 participants from each District will be conducted in the selected 14 districts. The major purpose of this interview is to ensure in-depth understanding of the results derived from the questionnaires. Further, the secondary data have been collected from several sources such as books, periodicals, library databases, conference proceedings, newspapers, published interviews, speeches, press releases, reports, electronic databases and existing literature for an in-depth analysis of social interaction among Buddhists and Muslims in Sri Lanka.

\section{Data Analysis}

Since this research adopts both qualitative and quantitative data, it will require two types of analyses that the descriptive analysis (questionnaires) and coding manually (interview) respectively. The questionnaires will be analysed by using the Statistical Package for Social Science (SPSS) software and the interviews will be analysed by manually. To achieve the findings of this study, simple frequencies, percentages and central tendencies (viz., mean, mode and standard deviation) will be calculated as well. The discussions and interpretations will start with 38 items of the questionnaire as this is a descriptive research. 


\section{Results and Discussion}

The analysis of the study is divided into four sections and carried out in that phase. All of received data was analysed in descriptive method with help of SPSS (Statistics package of social sciences). 59.7 percent of Sinhala Buddhists, 37.8 percent of Muslims and 1.8 percent of other ethnic groups are participated in this study of Buddhists and Muslims interaction in post-war context of Sri Lanka. The average method is followed here except for the primary method to achieve the objective of the study.

\section{Mixed Interaction Between Buddhists and Muslims}

Sri Lanka's 30-year civil war, which lasted almost a quarter-century, came to an end. Today, the repercussions of the war are still fresh on people's minds. This is evidenced by the recent ethnic conflicts in Sri Lanka. Especially, Sinhala-Muslim relations seen as a major challenge after the end of the civil war. In this context, five main situations were asked among the participants to find out the interaction between the two communities, and the level of communication between the two races was examined. The study's findings are clearly displayed in the following:

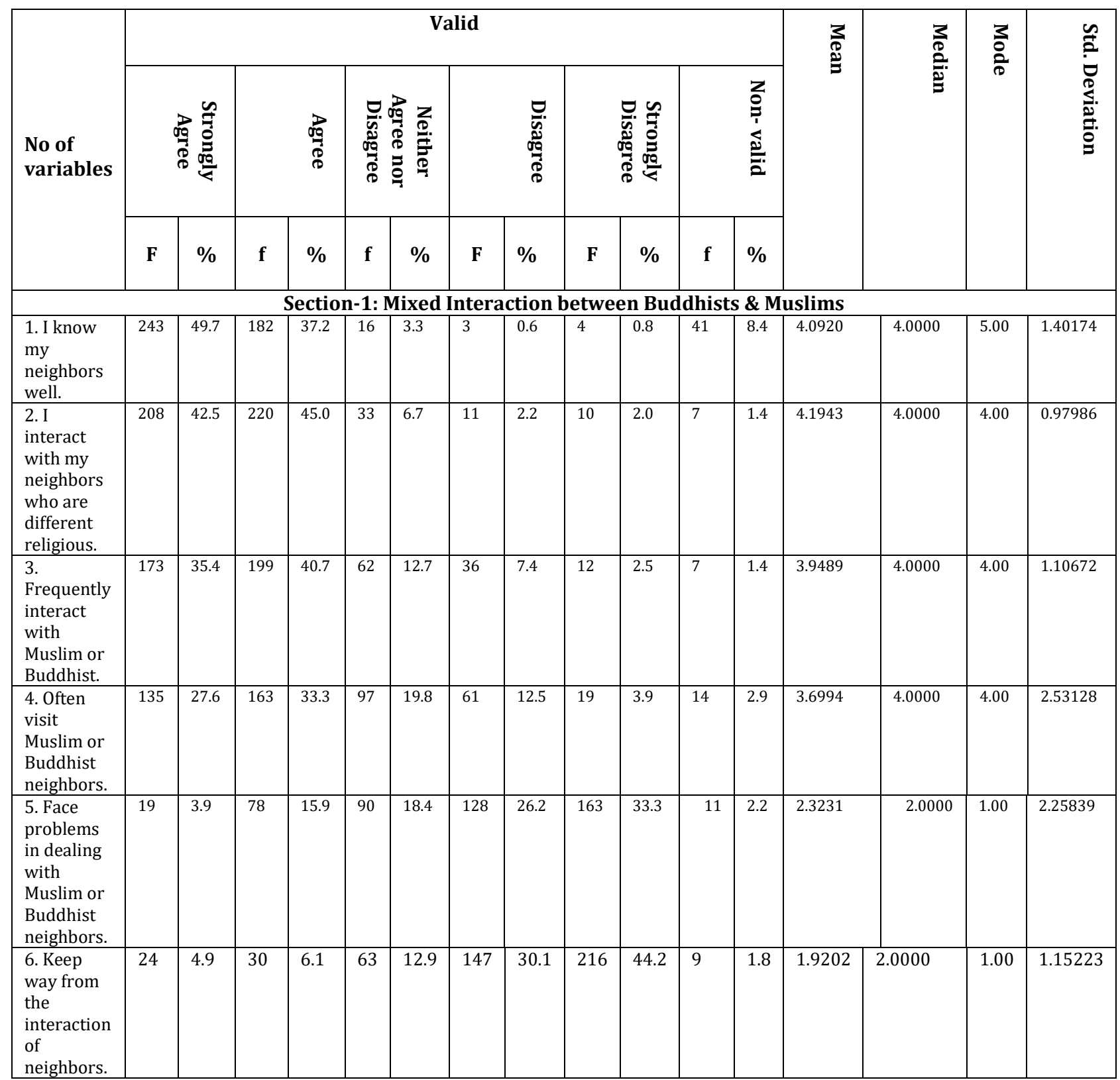


All the 14 districts of Sri Lanka where the survey was conducted are completely Muslim Sinhala mixed areas. Accordingly, the first question asked in this section is that: "Whether you know your neighbor well". When seeing the response of the participants in bulk, most of the participants (Mean: 4.0920, Mode: 5, Std.; 1.40174) are aware of their neighbors. It is commendable that the state in the study area is so great that it can be seen in many Western countries today without even knowing who their neighbors are.

Examining their experiences of establishing harmonious relations with such a neighbor who adheres to a particular religious practice, most of the participants (Mean: 4.1943, Mode: 4, Std. v: 0.97986) are aware that their neighbours are religiously diverse (Islam, Buddhism), and they have been able to have a smooth relationship with them. It indicates to the two parties' social interaction. When asked about their interactions with neighbors and the family visit to their house, majority of the participants (Q-3 Mean: 3.9489 and Q-4 Mean: 3.6994) mentioned that they were neutral. We were able to find out that both the communities have failed to hold family reunions and family visits despite maintaining business and personal interactions. When we asked the reasons during the interview, both sides mentioned some of their religious practices. It is noteworthy that the two religions are preaching harmony and brotherhood.

When questioned whether they had any disputes with their neighbours, participants denied any such inconsistency (Mean: 2.3231, Mode: 2, Std. v: 2.25839). In contrast, there have been a number of recent contradictory incidents are happened. We can perceive that all of this means that certain fundamentalist, hard-line movements were motivated. It seems that there is a good partnership between Sinhalese and Muslims who do not support fundamentalist, nationalistic movements and have a willingness to engage. Finally, as we investigated 'the keep away from neighborly contact', the majority of the participants firmly denied this (Mean: 1.9202, Mode:2, Std. v: 1.15). It can lead to the conclusion that the people want to live in a plural society in peace and harmony.

\section{Sharing Leisure Times Together}

This section examines five questions to determine whether the research participants are sharing their leisure time with their neighbors and how they feel when they are sharing.

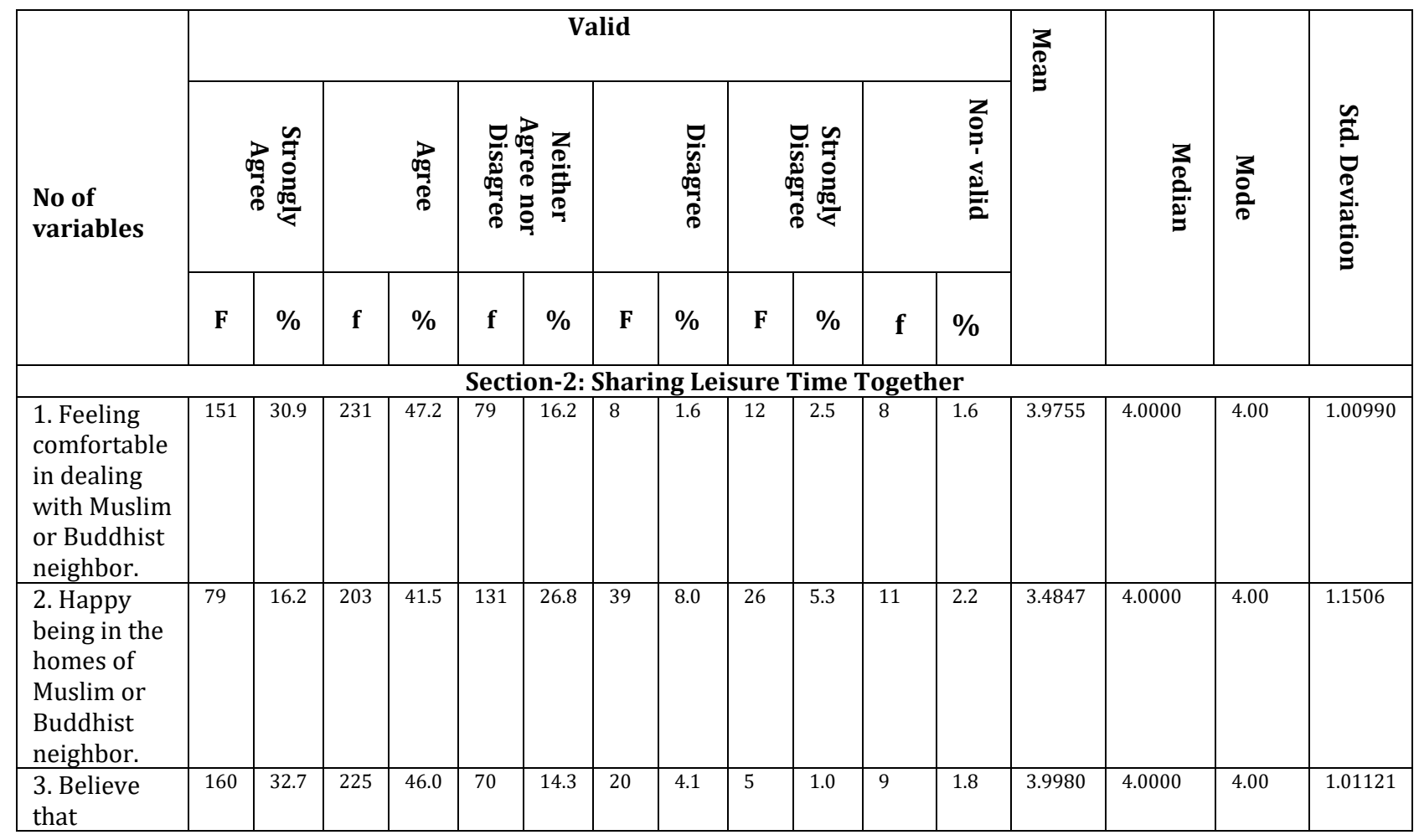

https://doi.org/10.24035/ijit.20.2021.206 


\begin{tabular}{|c|c|c|c|c|c|c|c|c|c|c|c|c|c|c|c|c|}
\hline $\begin{array}{l}\text { neighbors } \\
\text { are good. }\end{array}$ & & & & & & & & & & & & & & & & \\
\hline $\begin{array}{l}\text { 4. Believe } \\
\text { that } \\
\text { neighbors } \\
\text { are proud of } \\
\text { their } \\
\text { professed } \\
\text { religion. }\end{array}$ & 142 & 29.0 & 192 & 39.3 & 45 & 9.2 & 26 & 5.3 & 72 & 14.7 & 12 & 2.5 & 3.5521 & 4.0000 & 4.00 & 1.45487 \\
\hline $\begin{array}{l}\text { 5. Feeling } \\
\text { that } \\
\text { threatened } \\
\text { by the } \\
\text { different } \\
\text { religious } \\
\text { believers. }\end{array}$ & 23 & 4.72 & 32 & 6.5 & 59 & 12.1 & 135 & 27.6 & 231 & 47.2 & 9 & 1.8 & 1.8834 & 2.0000 & 1.00 & 1.15797 \\
\hline
\end{tabular}

Table 4: Sharing Leisure Time Together

When questioned whether they would feel comfortable interacting with a Muslim or Buddhist neighbor, the majority of the participants (Mean: 3.9755, Mode: 4, Std. v: 1.00990) said "yes", with only a few mentioning neutrality. According to the findings, people in the region were found to be in a healthy relationship, with no suspicions about the other religious brother. When we asked during the interview about this, most of them respond that "we have been living and doing business together for many year, thus, we did not feel such a sense of dread" (Interview).

Sri Lankans have a habit of going to their neighbors' houses in their spare time and sitting there for a while, engaging in deep conversation with them. During this time a long-term relationship develops. When asked whether they felt comfortable or fearful when visiting a neighbor's house to share leisure time together, majority of participants are agreed that they feel happy with their neighbors. This is seen in the minds of the participants who have a positive mentality free from the fear of war.

In order to assess the general opinion about the neighbors, they were asked, "Do you think your neighbor is good"? Most of the participants are accepting that they are good. What this shows is, that their interaction and understanding has progressed to the point where they can vouch for their neighbors. It is commendable that people are living smoothly in the study area. It's worth noting that when asked about this during the interview, majority of respondents did not point fingers at one another and instead listed healthy responses and positive experiences. It is prohibited to boast in Islam and Buddhism. Proud of their culture, beliefs and religion can be added to the side of fundamentalism. It's worth noting that majority of today's movements are becoming progressively proud of their ethnicity, faith, and beliefs while dismissing other cultures, religions, and beliefs. Sri Lanka is no exception for this. When we asked about the proud of their professed religion, majority of participants (Mean: 3.5521, Mode: 4, Std.v:1.4548) agreed. In today's Sri Lanka, racism is based around being proud of one's own religion while mocking others. When research samples asked about the potential danger of living in an environment where multi-religious people live and spend their leisure time with them, majority of participants (Mean:1.883, Mode: 2, Std. v: 1.15797) refused the matter. This indirectly indicates that the people of Sri Lanka want to live with respect for other religions.

\section{Religious Understanding, (Inter-Religious Understanding)}

The most important aspect that a man living in a pluralistic society should have is the understanding of religions. Many riots and infringement of rights in the name of religions are occur today mainly due to the lack of proper understanding of the teachings and guidelines of the religion in which they belong. The subject matter of the study has been undertaken with the view that the post-war context in Sri Lanka may be due to ignorance of the teachings and guidelines of equality which one follows as one of the reasons for the growing ethnic tensions between Islam and Buddhism. The following table describes the study's findings. 


\begin{tabular}{|c|c|c|c|c|c|c|c|c|c|c|c|c|c|c|c|c|}
\hline \multirow{3}{*}{ No of variables } & \multicolumn{12}{|c|}{ Valid } & \multirow{3}{*}{$\begin{array}{l}3 \\
\stackrel{3}{3}\end{array}$} & \multirow{3}{*}{$\stackrel{3}{2}$} & \multirow{3}{*}{$\begin{array}{l}3 \\
\frac{3}{0} \\
\frac{0}{0}\end{array}$} & \multirow{3}{*}{ 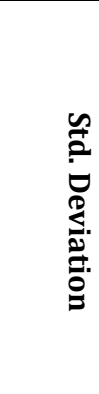 } \\
\hline & \multicolumn{2}{|c|}{ 褐导 } & \multicolumn{2}{|c|}{ 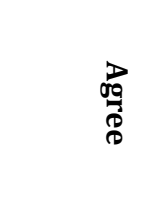 } & \multicolumn{2}{|c|}{ 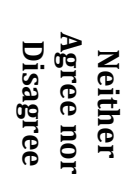 } & \multicolumn{2}{|r|}{ 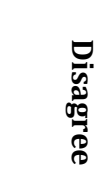 } & \multicolumn{2}{|c|}{ 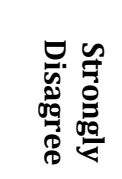 } & \multicolumn{2}{|r|}{ 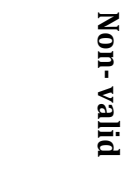 } & & & & \\
\hline & $\mathbf{F}$ & $\%$ & f & $\%$ & f & $\%$ & $\mathbf{F}$ & $\%$ & $\mathbf{F}$ & $\%$ & f & $\%$ & & & & \\
\hline \multicolumn{17}{|c|}{ Section -3 Religious Understanding, (I: Inter -religious understanding) } \\
\hline $\begin{array}{l}\text { 1. Understand own } \\
\text { religious teaching. }\end{array}$ & 304 & 62.2 & 150 & 30.7 & 9 & 1.8 & 5 & 1.0 & 11 & 2.2 & 10 & 2.0 & 4.4335 & 5.0000 & 5.00 & 1.01231 \\
\hline $\begin{array}{l}\text { 2. Frequently visit } \\
\text { house of worship for } \\
\text { fulfilling religious } \\
\text { rituals. }\end{array}$ & 183 & \begin{tabular}{|l|}
37.4 \\
\end{tabular} & 180 & 36.8 & 52 & 10.6 & 43 & 8.8 & 11 & 2.2 & 20 & 4.1 & 3.9427 & 4.0000 & 5.00 & 2.22891 \\
\hline $\begin{array}{l}\text { 3. Commit in } \\
\text { performing of } \\
\text { religious duties. }\end{array}$ & 232 & \begin{tabular}{|l|}
47.7 \\
\end{tabular} & 194 & 39.7 & 28 & $\begin{array}{l}5 . \\
7\end{array}$ & 17 & 3.5 & 8 & 1.6 & 10 & 2.0 & 4.2168 & 4.0000 & 5.00 & 1.0490 .3 \\
\hline $\begin{array}{l}\text { 4. Strictly follow own } \\
\text { religious teaching. }\end{array}$ & 217 & 44.4 & 191 & 39.1 & 33 & 6.7 & 26 & 5.3 & 12 & 2.5 & 10 & 2.0 & 4.1145 & 4.0000 & 5.00 & 1.12314 \\
\hline
\end{tabular}

Table 1: Religious Understanding, (Inter-religious understanding)

The majority of the participants (Mean: 4.4335, Mode: 5, Std. v: 1.01231) of both groups were found to be in a state of full understanding of their own religious teachings in the questions raised in order to examine their understanding of their own faiths and they also have the habit of going to their houses of worship and engaging in religious activities. As shown by this, both communities are well knowledgeable of their faiths. Therefore, it is possible to understand that there are study models that can follow the moral values and guidelines mentioned in the respective religions.

\section{Other Religious Understandings}

It is essential for everyone living in a multicultural environment to behave with an understanding of other religions. The results obtained in the query from the participants in this regard are described in the table.

\begin{tabular}{|c|c|c|c|c|c|c|c|c|c|c|c|c|c|c|c|c|}
\hline \multirow{3}{*}{ No of variables } & \multicolumn{12}{|c|}{ Valid } & \multirow{3}{*}{$\begin{array}{l}3 \\
\stackrel{3}{8} \\
\stackrel{0}{=}\end{array}$} & \multirow{3}{*}{ 起. } & \multirow{3}{*}{$\begin{array}{l}3 \\
\vdots \\
0 \\
0\end{array}$} & \multirow{3}{*}{ 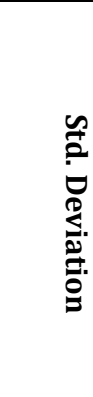 } \\
\hline & \multicolumn{2}{|c|}{ 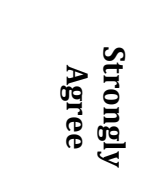 } & \multicolumn{2}{|c|}{$\begin{array}{l}\overrightarrow{00} \\
0 \\
8 \\
8\end{array}$} & \multicolumn{2}{|c|}{ 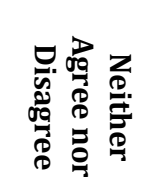 } & \multicolumn{2}{|r|}{ 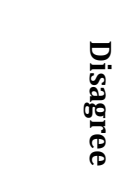 } & \multicolumn{2}{|c|}{ 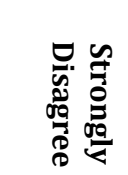 } & \multicolumn{2}{|r|}{$\begin{array}{l}z \\
0 \\
1 \\
\vdots \\
0 \\
0\end{array}$} & & & & \\
\hline & $\mathbf{F}$ & $\%$ & f & $\%$ & $\mathbf{f}$ & $\%$ & $\mathbf{F}$ & $\%$ & $\mathbf{F}$ & $\%$ & f & $\%$ & & & & \\
\hline \multicolumn{17}{|c|}{ (Section- 3, II Out -Religious Understandings) } \\
\hline $\begin{array}{l}\text { 1. Knowledge on } \\
\text { other religious } \\
\text { teaching like } \\
\text { Buddhism or } \\
\text { Islam. }\end{array}$ & 55 & 11.2 & 246 & 46.2 & 101 & 20.7 & 61 & 12.5 & 34 & 7.0 & 12 & 2.5 & 3.3497 & 4.0000 & 4.00 & 1.19013 \\
\hline $\begin{array}{l}\text { 2. Have ever learnt } \\
\text { about other } \\
\text { religions. }\end{array}$ & 45 & 9.2 & 168 & 34.4 & 104 & 21.3 & 97 & 19.8 & 64 & 13.1 & 11 & 2.2 & 3.0000 & 3.0000 & 4.00 & 1.28037 \\
\hline $\begin{array}{l}\text { 3. Have } \\
\text { understanding }\end{array}$ & 103 & 21.1 & 244 & 49.9 & 76 & 15.5 & 31 & 6.3 & 24 & 4.9 & 11 & 2.2 & 3.6912 & 4.0000 & 4.00 & 1.15266 \\
\hline
\end{tabular}




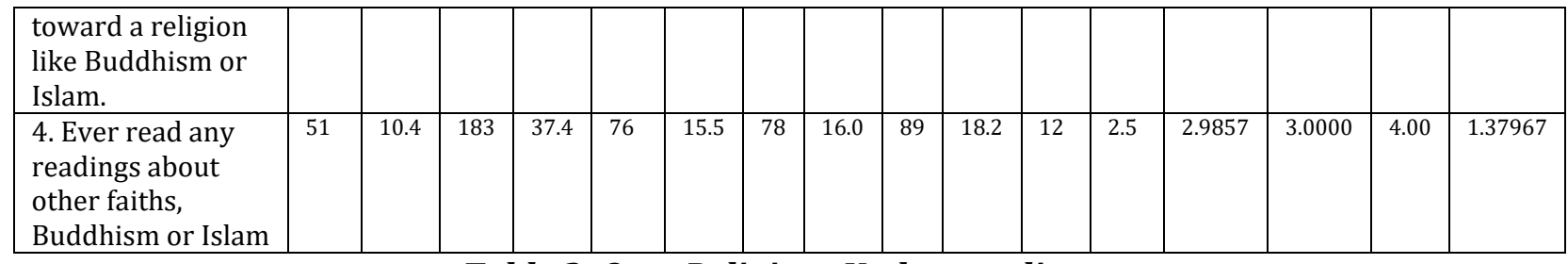

Table 2: Out -Religious Understandings

Four main questions were raised among the participants regarding this section. When asked about their understanding of Islam and Buddhism, as well as the teachings of other faiths, it was discovered that majority of them had no idea. What can be learned from this is that, the reason for the lack of understanding of other religions is that people do not make the effort to study and understand other religions. When discussing with research models on this, their spiritual scholars, they did not emphasize the significance of studying and understanding other faiths, as well as the absence of a sense of nature. This made it possible to understand the need to provide awareness on other religions in the study area and to ensure that no action was taken.

\section{Workplace Interaction}

In general, the workplace is a place where people of various races come together to work for themselves, a company, or the government. In a working environment, there are two types of people: job providers and workers. The level of interaction in the work environment is studied in order to investigate the level of cooperation between co-workers whether they are of different religious beliefs and adherents of different religious teachings. The results obtained in the query from the participants in this regard are described in the table.

\begin{tabular}{|c|c|c|c|c|c|c|c|c|c|c|c|c|c|c|c|c|}
\hline \multirow{3}{*}{ No of variables } & \multicolumn{12}{|c|}{ Valid } & \multirow{3}{*}{$\begin{array}{l}3 \\
\stackrel{8}{3} \\
\stackrel{3}{3}\end{array}$} & \multirow{3}{*}{$\frac{3}{2}$} & \multirow{3}{*}{$\frac{3}{0}$} & \multirow{3}{*}{ 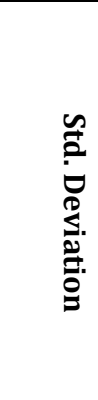 } \\
\hline & \multicolumn{2}{|c|}{ 兽导 } & \multicolumn{2}{|r|}{ 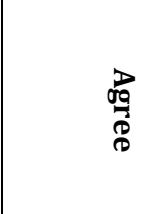 } & \multicolumn{2}{|c|}{ 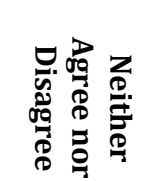 } & \multicolumn{2}{|r|}{ 兽. } & \multicolumn{2}{|c|}{ 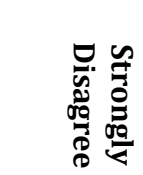 } & \multicolumn{2}{|r|}{ 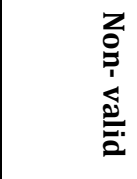 } & & & & \\
\hline & $\mathbf{F}$ & $\%$ & f & $\%$ & f & $\%$ & $\mathbf{F}$ & $\%$ & $\mathbf{F}$ & $\%$ & f & $\%$ & & & & \\
\hline \multicolumn{17}{|c|}{ (Section- 4, workplace interaction) } \\
\hline $\begin{array}{l}\text { 1. Worked with } \\
\text { Buddhists or } \\
\text { Muslims in trade } \\
\text { surroundings } \\
\text { Buddhist or } \\
\text { Islam. }\end{array}$ & 215 & 44.0 & 199 & $\begin{array}{l}40 . \\
7\end{array}$ & 35 & 7.2 & 14 & 2.9 & 15 & 3.1 & 11 & 2.2 & 4.1288 & 4.0000 & 5.00 & 1.11701 \\
\hline $\begin{array}{l}\text { 2. Have close } \\
\text { relationship } \\
\text { there. }\end{array}$ & 178 & 36.4 & 184 & 37.6 & 65 & 13.3 & 33 & 6.7 & 17 & 3.5 & 12 & 2.5 & 3.8937 & 4.0000 & 4.00 & 1.20999 \\
\hline $\begin{array}{l}\text { 3. Feeling } \\
\text { comfortable in } \\
\text { working } \\
\text { surrounding. }\end{array}$ & 128 & 26.2 & 204 & 41.7 & 102 & 20.9 & 25 & 5.1 & 20 & 4.1 & 10 & 2.0 & 3.7464 & 4.0000 & 4.00 & 1.14390 \\
\hline $\begin{array}{l}\text { 4. Thinking that } \\
\text { understand other } \\
\text { religious } \\
\text { obligations in } \\
\text { workplace. }\end{array}$ & 112 & 22.9 & 218 & 44.6 & 105 & 21.5 & 26 & 5.3 & 14 & 2.9 & 14 & 2.9 & 3.7076 & 4.0000 & 4.00 & 1.13548 \\
\hline $\begin{array}{l}\text { 5.There are } \\
\text { segregations of }\end{array}$ & 21 & 4.3 & 88 & 18.0 & 103 & 21.1 & 91 & 18.6 & 16.6 & 33.9 & 20 & 4.1 & 2.2781 & 2.0000 & 1.00 & 1.32146 \\
\hline
\end{tabular}




\begin{tabular}{|c|c|c|c|c|c|c|c|c|c|c|c|c|c|c|c|c|}
\hline $\begin{array}{l}\text { religious groups } \\
\text { in work trade. }\end{array}$ & & & & & & & & & & & & & & & & \\
\hline $\begin{array}{l}\text { 6. Feeling that } \\
\text { Muslim or } \\
\text { Buddhist are } \\
\text { backward person } \\
\text { in the workplace. }\end{array}$ & 16 & 3.3 & 56 & 11.5 & 103 & 21.1 & 132 & 27.0 & 16.4 & 33.5 & 18 & 3.7 & 2.1288 & 2.0000 & 1.00 & 1.32546 \\
\hline
\end{tabular}

Table 3: Workplace Interaction

When asked if they wanted to collaborate with people of other religions in a pluralistic environment, majority of them (Mean: 4.1288, Mode: 4, Std. v: 1.11701) were agreed with this. That is the explanation why the research participants choose to live in peace with people of other faiths. It is also worth noting that they maintain a close intersection while working like this.

Majority of participants (Mean: 4.1288, Mode: 4, Std. v: 1.11701) stated that when working in a workplace with people of various religious backgrounds, they function with an independent mind-set free from fears and inconveniences. In this way, the working environment can be understood as an environment conducive to making harmonious relationships. 'Muslims are generally seen as a famous business community rather than others in Sri Lanka' (Razick 2017). Their past evidence supports this. The pre-war trading relationship between Muslims and Buddhists was cordial, however the post-war situation has deteriorated. Past experiences show that the halal issue in Sri Lanka in particular, has been fertilized. It is commendable that there is a harmonious relationship in the work environment though, so many bitter incidents happened. Samples agree (Mean: 3.7076, Mode: 4, Std. v: 1.13548) that knowledge of other religions is necessary and deny division on ethnic and religious grounds. As a result, we can see that the participants have a mentality of living together in a diverse setting. When it comes to research on reactionary thought in the workplace, majority of participants have denied this. This the healthy situation in the research area.

\section{Major Findings of the Study}

1. In Islam and Buddhism, there are clear guidelines for social interaction. It's a marvel linked to religious belief. The Quran clearly states how to maintain harmonious relations with nonMuslims. Muslim scholars said that 'birr' is the foundation of the social interaction between Muslims and Non-Muslims.

2. Buddhism also promotes its adherents towards peaceful and harmonious way of living. In order to Buddhists to attain peace in this life, tolerance should be practiced. Buddhism is to guide every human towards a noble life without harming other persons, cultivate humane qualities in order to maintain human dignity, spread out all-embracing kindness without any discrimination, train the mind to avoid evil and purify the mind to gain peace and happiness.

3. Most of the participants are aware of their neighbors and they have been maintaining a smooth relationship with them. They denied the experience of conflicts and fights with his neighbor and Majority of them firmly denied keep away from neighborly contact. Sri Lankans want to live in a plural society in peace and harmony. Most of them are accepting that their neighbors are good.

4. Majority of participants were proud of their professed religion. In today's Sri Lanka, racism is based around being proud of one's own religion while mocking others. Majority of the participants of both groups were found to be in a state of full understanding of their own faiths and they also have the habit of going to their houses of worship and engaging in religious activities. Majority of participants had no idea about other faith, religious guidance and understanding and they not to get involved in trying to learn about other religions, to get a proper understanding. They wanted to collaborate with people of other religions in a pluralistic working environment.

5. When working in a workplace with people of various religious backgrounds, they function with an independent mind-set free from fears and inconveniences. Samples agreed with that the knowledge of other religions is necessary and deny division on ethnic and religious grounds. 
To conclude, Muslim and Buddhist groups living in this country will be able to communicate with their neighbors, spend leisure time together, and understand Buddhist and Muslim harmony in the workplace in order to understand how or what their relationship looks like.

Although the relationship between the two communities is generally seen to be in a healthy state, the non-compliance of a few notable features has exacerbated the tension between the two communities. Among them are study participants who, while keeping close relationships with their neighbours, sometimes refrain from engaging in family interaction due to religious activities, rituals, and the fact that they do not necessarily have those feelings, The absence of such contacts as a family, even when making personal visits for business or other purposes, although there is some knowledge of their own religious teachings and guidelines, there is no knowledge or awareness of other religions and also both communities have failed to take efforts to learn it. Lack of understanding of other religions is a barrier to maintaining a harmonious relationship in the workplace, some of the participants have a reactionary mind-set and a tendency to be religiously esteemed, which has led to scepticism and marginalization of people of other faiths. As this situation continues to escalate, it is likely that in the future the two communities will clash and a state of war will develop, and the expectation of some fundamentalist movements may be fulfilled.

\section{References}

Ahamed Sarjoon Razick, Ahmad Sunawari Long \& Kamarudin Salleh. 2015. Historical relationship between Buddhists and the Muslims in Sri Lanka. Mediterranean Journal of Social Sciences: MCSER Publishing, 278-284.

Ahamed Sarjoon Razick, Mohamed Anifa Mohamed Fowsar \& Abdul Kalik Mihlar. 2020. Factors affecting ethnic harmony between Sinhalese and Muslim commmunities in post-war Sri Lanka: A study based on South Eastern University of Sri Lanka. Journal of Politics and Law. 1-10.

Ahmad Sunawari Long, Khaidzir Hj.Ismail, Kamarudin Salleh, Saadiah Kumin, Halizah Omar \& Ahmed Sarjoon Razick. 2016. An Analysis of the post-war community relations between Buddhists and Muslim in Sri Lanka: A Muslim's perspective. Journal of Politics and Law, 42-54.

Borgatta, E. F. \& Marie L. Borgatta. 1992. Improving inter-cultural interactions: models for cross-cultural training programs. California: Sage Publications.

Department of Census and Statistics. 2012. Statistical Abstract of the Democratic Socialist Republic of Sri Lanka. Sri Lanka: Department of Census and Statistics.

Di Zi Gui: Guide to a Happy Life. 2005. Toowoomba, Australia: Pure Land Learning College Assn. Inc. Pure Land Books.

Engku Alwi, E.A. and Zaki \& Mohd Rashid Z.B. 2011. Cross Religious and social interaction: a case study of Muslims and Buddhists in Kampung Tendong, Pasir Mas, Kelantan. Asian Social Science, 1:112-128. DOI: 10.5539/ass.v7n8p11

Razick, A. S. 2017. Socio-cultural issues and the relationships between Buddhists and Muslims in Sri Lanka. 4th International Symposium 2017 - (pp. 12-20). Oluvil, Sri Lanka: Faculty of Islamic Studies and Arabic Language.

Rifai, S. 2013. Patriotism, allegiance and loyalty of Sri Lankan Muslims to mother Lanka, Colombo Telegraph.

Yehiya.R. 2013. Aymmetic relationship of buddhist- Muslim bond in Sri Lanka: https://groundviews.org/2013/06/01/the-asymmetric-relationship-of-buddhist-muslimbond-in-sri-lanka/. Retrieved date: 6 Januaray 2013. 